\title{
UM CURSO EM FORMAÇÃO: CORPO, ARTE E NATUREZA - UNIRIO
}

\author{
Greice Duarte de Brito Silva ${ }^{\mathrm{i}}$ \\ Adrianne Ogeda Guedes ${ }^{\text {ii }}$ \\ Nuelna Vieira ${ }^{\text {iii }}$ \\ Michelle Dantas Ferreira $^{\text {iv }}$
}

\section{RESUMO}

O texto apresenta o Curso de Extensão em Educação Infantil: Corpo, Arte e Natureza - seus caminhos e percursos - firmados a partir do convênio entre MEC e a Universidade Federal do Estado do Rio de Janeiro (UNIRIO). As propostas de organização e funcionamento do curso são alinhavadas às reflexões acerca da formação continuada dos professores de Educação Infantil. Não procuramos, contudo dar um cunho prescritivo, pois cremos que mais importante do que fornecer "receitas" do trabalho a ser realizado com as crianças, é propiciar vivências que tem os professores como protagonistas. É necessário que o docente experimente uma Educação Estética, aguçando seus sentidos, ampliando repertórios, vivenciando momentos que vão além da reflexão, pois se circunscrevem no corpo e acendem as emoções.

Palavras chave: Formação de professores; Corpo; Arte; Estética

\section{RESUMEN}

El artículo presenta la formación de Curso de Extensión de educación de la primera infancia: el arte del cuerpo y la naturaleza - sus caminos y rutas - firmados a partir del acuerdo entre el MEC y la Universidad Federal del Estado de Río de Janeiro (UNIRIO). Las propuestas de organización y funcionamiento del curso están clavadas reflexiones sobre la educación continua de los profesores de la educación de la primera infancia. No buscamos, sin embargo dar un carácter prescriptivo, ya que creemos que más importante que proporcionar " ingreso " del trabajo que se realiza con los niños, es proporcionar experiencias que tienen los docentes como protagonistas. Es necesario que el maestro pruebe una educación estética, afilando sus sentidos, la ampliación de repertorios, experimentando momentos que van más allá de la reflexión como confinado en el cuerpo y las emociones de luz.

Palabras clave: Formación del Profesorado; Cuerpo; Arte; Estética 


\section{Para iniciar a conversa}

Atuamos na formação de educadores há muitos anos e o desafio que nos move é encontrar meios de ampliar, nos que convivem diariamente no ambiente escolar - educadores e crianças - a escuta, o olhar, as possibilidades de cada um e do grupo. Propusemo-nos a esse desafio; pois entendemos aprendizagem como um ato de transformação, de trocas, no qual agregamos valores e alteramos nossa forma de ser e pensar. Um caminho que reconhecemos como favorável a essa ideia de aprendizagem é uma formação do educador sensível às formas de ser da criança de zero a seis anos de idade. Assim, buscamos um olhar para as linguagens mais presentes na Educação Infantil e encontramos no corpo, com suas possibilidades de expressão e relação, um lugar para qualificarmos as práticas cotidianas entre educadores e crianças. Sabemos que nas interações escolares o corpo é um canal de contato, entre o individual e o grupo, o outro, o espaço, os materiais, enfim, as relações que estabelecemos nas nossas práticas diárias. Nesse percurso de formação temos como desafio: aprimorar o corpo do educador, tornando-o mais sensível à escuta, ao olhar, ao tato, ao movimento, enfim, a própria estrutura corporal que nos habilita a estar nas relações, no mundo, estabelecendo contatos com diversas pessoas, saberes e modos de ser; conhecer técnicas corporais que possibilitem maior autoconhecimento; compreender as conexões entre consciência de si (consciência corporal) e aprendizagem, desenvolvimento e relacionamento; aguçar nos educadores a vontade de perceber-se, reconhecendo em suas práticas cotidianas as marcas e os valores que os guiam. Convidamos os educadores a se aproximarem de um corpo sensível, numa tentativa de estreitarem sensações, sentimentos e ações. É comum falarmos sobre as crianças, sobre a infância e sobre o educador. No entanto, queremos instigar o educador a falar de si, do que sente, quer e pensa, pois como bem nos provoca Vianna (1998, p. 11-12) entedemos que "Nossa história se inscreve em nosso corpo e os movimentos são reflexos de emoções e sentimentos" (apud RESENDE, 2008, p. 564). Assim, no processo de formação há uma necessidade de que o educador se sinta implicado e pertencente as suas questões e necessidades. Dessa forma, buscamos uma formação ocupada do que nos torna mais humano, as sensações, percepções e emoções. Buscamos um corpo que conte suas histórias e que esteja disponível para viver tantas outras no dia a dia da escola. Foi pautado nesses preceitos que o Curso de Extensão: corpo, arte e natureza aconteceu na Universidade Federal do Estado do Rio de Janeiro (UNIRIO) em parceria com o Ministério da Educação (MEC).

\section{Uma primeira experiência: desafios de formar pela experiência.}


"Uma educação do sensível só pode ser levada a efeito por educadores cujas as sensibilidades tenham sido desenvolvidas e cuidadas."

(DUARTE JR., 2010, p.31)

Em 2013 oferecemos na UNIRIO o primeiro Curso de extensão voltado para professores da Educação Infantil pelo Convênio entre o MEC e os Institutos Federais. O público alvo era composto por docentes das Instituições públicas do Rio de Janeiro (Creches e Pré-escolas) e atendeu cerca de quarenta professores, predominantemente do sexo feminino. O tema do curso, definido após levantamento prévio realizado pelo MEC via plataforma Freire, abrangia a infância e as artes, sendo que cada universidade proponente teve a liberdade de ajustar o curso oferecido de acordo com seus interesses e possibilidades. Assim a primeira proposta elaborada buscou oferecer experiências no campo das artes visuais, expressão corporal, dança, teatro, cinema e literatura. Cada um deles distribuído em módulos com duração aproximada de quatro encontros, sempre realizados aos sábados por um período de quatro horas, nas dependências da UNIRIO. A ênfase maior foi dada as experiências focalizadas no corpo e no movimento por considerarmos ser essa uma dimensão pouco presente nos espaços formativos de que tínhamos notícias, tanto na formação inicial do professor (Cursos de Pedagogia) quanto nas formações continuadas. Como bem nos coloca Vianna (1998, p. 11-12), “O corpo é um meio de expressão, não um meio de atuar automático. O trabalho corporal desenvolve a sensibilidade, a imaginação, a criatividade e a comunicação" (apud RESENDE, 2008, p. 564).

A possibilidade de expressar, imaginar, criar e comunicar florescem nos primeiros seis anos de vida e se manifestam por meio de gestos, movimentos, falas e expressões variadas. A criança fala com o corpo inteiro, e/ou como nos diz Maturana (2001, apud PENA, BOGÉA e BORGES, 2008, p. 31): "viver é sinônimo de conhecer (...) o ser humano aprende com o corpo inteiro". Portanto, todo o conhecimento pretendido à criança passará pelo seu corpo, desde dores a sabores. E isso requer um educador que escute essas diversas formas de expressão. Dessa forma, entendemos que as habilidades do educador em afetar e ser afetado, assim como seus saberes sobre sua respiração e eixo-corporal, por exemplo, são primordiais, pois revelam um modo de estar com o outro, uma possibilidade de escutar e perceber esse outro.

Nessa primeira proposta convidamos para lecionar no curso de extensão, professores e artistas dos diversos campos abordados. Interessava-nos que os professores cursistas tivessem contato com profissionais que não apenas trabalhavam com formação, mas que também estavam envolvidos com a experiência criativa. Como parte da proposta do curso, incluímos idas aos espetáculos que estavam em cartaz dos professores convidados para as aulas de dança e de teatro. As premissas teórico metodológicas que fundamentaram as estratégias que priorizamos, tais como 
garantir espaços de vivências em todos os encontros, se assentavam na compreensão de que a formação de professores precisa necessariamente envolver o plano das vivências estéticas. Por estética tomamos o conceito utilizado por Freire (1986), como algo que acontece na realidade, nas relações, na escola, na sala de aula, chegando a dizer que "é impossível educar sem fazer uma experiência estética" (apud TREZZI, 2011, p. 74). A estética da qual falamos é então, algo visceral, ou seja, que vem de dentro, ou que nos atinge por dentro, despertando e/ou aguçando sentidos, nos atravessando e afetando. O estético reside nas vivências e no que fazemos com elas, como bem nos diz Duarte Junior:

Educar os nossos sentidos para que eles nos permitam mais e mais saborear as sutilezas do mundo creio ser o primeiro passo para uma vida feliz e autocentrada. A competição desenfreada (rumo ao nada) nos impede de ter prazer com o fato de estarmos vivos, e esse prazer é, em sua essência, estético (grifo nosso). (DUARTE JR., 2012, p. 365).

Tarefa complexa e desafiadora que experimentamos diariamente ao fazer esse curso. A princípio, o que entendemos por aprendizagem, implica um investimento na expressão singular de cada aluno. Por isso, cuidamos minuciosamente do que chamamos de pontos de partida, ou seja, promovemos aulas que tinham como estrutura básica uma vivência. A aula como um ponto de partida para que cada integrante do grupo pudesse, de acordo com a vivência - que é sempre singular e indivisível - produzir sentidos, percepções, pensamentos, vida.

A vivência é uma unidade na qual, por um lado, de modo indivisível, o meio, aquilo que se vivencia está representado - a vivência sempre se liga àquilo que está localizado fora da pessoa - e por outro lado, está representado como eu vivencio isso, ou seja, todas as particularidades da personalidade e todas as particularidades do meio são apresentadas na vivência, tanto aquilo que é retirado do meio, todos os elementos que possuem relação com dada personalidade, como aquilo que é retirado da personalidade, todos os traços de seu caráter, traços constitucionais que possuem relação com dado acontecimento. Desta forma, na vivência, nós sempre lidamos com a união indivisível das particularidades da personalidade e das particularidades da situação representada na vivência. (Vigotsky apud SCHLINDWEIN, 2010, p. 35)

O aspecto vivencial é um caminho de propiciarmos a expansão corporal em cada pessoa. É dessa forma que entendemos que a aprendizagem acontece - em uma experiência de corpo inteiro, integrada, produzindo sentidos e conexões.

Vários foram os desafios surgidos desse primeiro curso: como nos aproximar do que cada aluno vivencia? Como saber de suas conexões e saberes entre as vivências e suas referências prévias pessoais? Quais sentidos estavam criando, recriando, afirmando? Enfim, havia um espaçotempo para vivências e precisávamos cuidar de criarmos outros momentos para escutarmos o vivido, abrir espaço para que os cursistas expressassem suas aprendizagens. Um momento coletivo 
no qual, à medida que partilhamos com o outro, escutamos sentidos diversos dos nossos, percebemos o quanto a vivência, única e indivisível, abre um espectro de possibilidades, direcionando cada um para um lugar específico. Necessitávamos promover uma maior articulação entre o vivido e a prática pedagógica.

\section{Articulando e aproximando da prática do professor!}

Pode-se perceber então que tínhamos - desde o primeiro curso em 2013 - como questão inquietante nos aproximar do que faz com que as experiências formativas favoreçam as transformações das práticas. Fica claro que não partimos aqui - e nem poderíamos - de uma visão de formação de professores que toma o professor como "reciclável", olhando para seus saberes como insuficientes e apostando que o que temos a oferecer é necessariamente melhor e mais consistente. O que nos mobiliza é um olhar que envolve o professor e seus saberes, que não concebe uma formação prescritiva cujas palavras são palavras de ordem, diretivas e com tom mandatório. No entanto, também não podemos desconsiderar o compromisso do formador com as conquistas no campo dos direitos da criança e com a garantia de um cotidiano nas creches e préescolas que tomem a criança como sujeito de direitos, cidadão, que cria e se relaciona com o mundo de forma ativa e sensível, e que precisa ter garantido espaços de brincar, de se relacionar, de se expressar, ser ouvido, etc. (explorar as diretrizes não como ordem, mas como fonte de concepções sobre as crianças e suas necessidades para uma vida feliz e plena). Também nos interessa pensar esse professor como sujeito criativo, que tem direitos, que tem um corpo, sensações, desejos, necessidades. Para as quais muitas vezes pouco tempo e espaço garante.

Consideramos que algumas inquietações capturadas nas falas dos professores cursistas nos indicavam necessidades que precisávamos escutar. Não nos eram ditas explicitamente, mas uns e outros trocavam suas impressões e essas nos chegavam, como pistas indiciárias que revelavam expectativas. Interessava-nos escutá-las. Diziam alguns que sentiam falta de mais "dicas sobre o que fazer com as crianças". Para outros, ser convidado a envolver-se em vivências em que não se percebia claramente a relação com a prática com as crianças, era sentido como algo estranho, pouco compreensível ou mesmo desnecessário.

De certo que escutar essas entrelinhas nos provocava a pensar em estratégias que pudessem tocar nas questões do cotidiano sem, contudo, tomar um caráter de receituário. Não queríamos isso! Também insistíamos - essa confiança alicerçava nossas escolhas - que as experiências estéticas precisam ser vividas inicialmente pelo professor para ele mesmo. Sem fins de transposição para as crianças necessariamente. Ele precisa perceber em si mesmo sua capacidade 
criativa, brincante, dançante, etc. Mas... Para alguns parecia difícil tomar parte dessa proposta. Para outros, ao contrário, o curso trazia movimento de mudança. Procuravam-nos, estavam afetados.

Todo o processo do curso de extensão foi devidamente avaliado pelos alunos, apontando sugestões, críticas e elogios. Nessa análise contínua ficou evidente o quanto o curso provocou alterações nas professoras que se identificaram com essa linguagem, com essa forma de estudar, e assim, narraram a importância deste em suas práticas cotidianas. Elas ressaltaram o quanto o curso foi transformador, pois ao longo do processo desconstruíram alguns saberes cristalizados, muitas práticas foram consolidadas e buscaram refletir, questionar e agir de acordo com o grupo e o contexto. Essa característica que o curso tem legitimado como marca própria, expõe um modo de estudar, de pensar as relações entre teoria e prática tão necessárias à prática docente. Esse é um dos efeitos que podemos identificar: professores potentes, criativos, desejosos de saber mais e criar, alteram suas práticas.

"Esse curso tem me acordado. Cada sábado eu acordo mais um pouco. Ele tem acordado meus repertórios de olhar, de sentir, de tocar. Eu mesma. Eu tenho sentido isso, um auto acordar. Eu lembrando da minha escuta, da minha música, das minhas cores. Lembrando de olhar para os lados do meu corpo, pro meio do meu corpo. Como se meu corpo fosse um rio e eu fosse de uma margem a outra. Hoje me vi acordando meus pés. Como ele se movimenta. Da mesma forma que eu venho me acordando tenho acordado as crianças com as quais trabalho. Sentir o chão, observar as cores, as texturas. Isso me tem feito dar um grande salto. (Professora Mônica Rosa, depoimento concedido em 2013)"

Este dado nos possibilita pensar, enquanto formadores, o quanto é imprescindível sustentar uma formação docente, na qual os professores se sintam pensando, pensantes e autores de sua prática. Há um deslocamento, deixam o lugar das lamúrias e queixas e tomam para si o lugar das possibilidades, dúvidas e vontades. Nesse outro lugar, o professor se torna potente e ativo em suas formas de agir e pensar. Logo, o efeito na sala de aula é automático. Um professor ativo com crianças ativas, resultando em experiências ricas e diversas.

O percurso experienciado por este grupo foi registrado de diversas formas. Fotografamos, entrevistamos os participantes, propusemos a feitura de um Álbum da vida - livrão em que eles registravam com diferentes recursos as experiências, reflexões vividas ao longo do curso. Os depoimentos e registros traziam os afetamentos do grupo. Revelavam descobertas. Nesse sentido, utilizamos o conceito trazido por Espinosa (1957, p. 144) ao ressaltar que "afetividade é a capacidade do homem de afetar e ser afetado (affectus), ao mesmo tempo em que é o resultado corpóreo e mental dessas afecções, ao que ele denomina affetio (afeto)" (apud SOARES, 2008, p. 46). Ou seja, os sujeitos envolvidos no curso participavam de vivências que provocavam sensações 


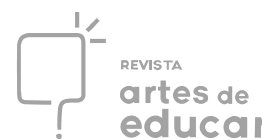

que se apresentavam de diversas formas e que tinham diferentes naturezas. $\mathrm{O}$ modo como esses corpos respondiam ou não ao que se passava nas propostas conduzia esses afetamentos, como um interruptor que traz luz à escuridão ou o sorriso que pode alegrar um coração. Uma coisa era certa: o curso impactava de forma mobilizadora os professores e alunos envolvidos.

Ainda assim, a pergunta que nos acompanhava era: de que forma essa mobilização, essas experiências que puderam afetar o grupo, trazia alterações nas práticas docentes? De que forma conhecer mais o próprio corpo, por exemplo, favorecia a reflexão do professor com relação ao movimento corporal da criança e seus espaços de liberdade e expressão? De que forma o mergulho, ainda que rápido, na literatura infantil, garantia uma lida com a mesma de forma crítica no cotidiano das escolas?

\section{Novos percursos: viver, contar, trocar, ARTICULAR.}

"Todos os sábados algumas pessoas se dirigiam a Praia Vermelha, na Urca, bairro da cidade do Rio de Janeiro. Em comum, roupas frescas e leves, por vezes o dia era de sol e muito calor. Enquanto algumas pessoas tinham o desejo de aproveitar paisagens e passear, outras tinham na cabeça ideias e expectativas sobre como seria a formação continuada no curso de extensão: arte, corpo e natureza." Greice Duarte.

$\mathrm{Na}$ busca por meios de escutar mais e mais essas vozes subjetivas, tão presentes no dia a dia das escolas, reformulamos o curso quando o oferecemos em 2014, com outras duas turmas. As vivências ainda aconteceram em sua maioria nas dependências da UNIRIO, sempre aos sábados com quatro horas de duração. Seguimos optando por oferecer um curso que fosse marcado pela proposição de vivências, articuladas com as reflexões teóricas e os espaços de troca e compartilhamento de experiências docentes. Para dar maior conforto aos cursistas e professores especialistas na realização dessas vivências essas duas turmas foram divididas em três grupos. Eram aproximadamente vinte e cinco por turma que a cada sábado experimentavam e compartilhavam das propostas de um professor especialista, divididos por módulos: Arte, Corpo, Dança, Literatura e Teatro. Cada um deles com a duração aproximada de três encontros, da mesma forma que no curso anterior.

O desafio dessa nova versão do Curso de Extensão era buscar caminhos que articulassem mais explicitamente os desafios e questões do cotidiano nas escolas, sem abrir mão da vivência estética, coração do curso. Dessa vez incluímos em sua estrutura um espaço-tempo de articulação mais explícito entre o que os cursistas viviam com os professores especialistas - novamente, em sua maioria, profissionais das artes, criadores - e as questões do cotidiano com as crianças. Para 
isso, convidamos duas das alunas-professoras integrantes da turma de 2013. Apostamos que a proximidade entre professoras formadoras e professores cursistas traria uma cumplicidade e certa identificação que favoreceria o reconhecimento do formador como um par. Assim como ele, professor da rede pública, vivendo os desafios de um cotidiano em que limites e possibilidades se faziam presentes. Mas, qual seria o papel desses articuladores? Firmes na convicção de que não aprendemos sem que nos seja garantido espaço de expressão de nossos saberes, de elaboração das experiências vivenciadas, sabíamos também que era preciso problematizar as práticas existentes, sobretudo as no campo das artes. Depoimentos das próprias participantes do curso de 2013 - que acabaram sendo uma das bases para o reformular dessa nova proposta - indicavam o quanto a arte na escola ainda possui, mais das vezes, um caráter ornamental. São os chamados “trabalhinhos", muitas vezes todos iguais; as músicas modeladoras de comportamento; gestos repetitivos tomam o lugar de expressões significativas e espontâneas. Assim, queríamos garantir que os espaços coordenados pelas professoras formadoras tivessem como foco abrir espaço para trocas entre os integrantes, relacionando a experiência vivida no curso com as questões da escola e também espaço para ampliar repertório, problematizar práticas usuais, instigar a experimentação de novas possibilidades.

Os encontros aconteciam sempre após as aulas com os formadores especialistas - que duravam em média três horas - e traziam à tona questões pertinentes ao chão da escola, pois buscávamos articular as falas; propondo vivências cabíveis às múltiplas realidades que tínhamos naquele pequeno universo de aproximadamente oitenta alunos. Cada uma dessas vivências - de aproximadamente uma hora - pretendia aguçar sensações, exercitando olhares e escutas mais sensíveis. O primeiro módulo do curso foi o de Artes e para o início do trabalho de articulação tivemos que planejar os encontros com os professores cursistas ao fim das oficinas. Estávamos curiosas e nos aventurávamos no terreno da experiência como mediadoras com perguntas que nos rondavam: o que esperam esses professores das atividades? E de nós, articuladoras? Mas, principalmente, o que esperam estes do curso de extensão?

Para os primeiros encontros trouxemos diferentes conceitos sobre arte para discutir com o grupo. Eles já haviam trocado e se apresentado nas vivências iniciais, então optamos por fazer como uma continuidade. Nas frases sobre arte, educação e infância muitas falas sobre a arte como algo muito importante, relacionada a acesso cultural e indisponível a todos. E sobre como fazem arte com as crianças. Percebemos que já saltavam as reflexões trazidas nos primeiros encontros, como “... às vezes esquecemos que a criança precisa de liberdade para pensar e criar, e muitas vezes ficamos presos pelo sistema a somente ensinar." Como planejado, nesta oportunidade conversamos sobre o que é arte. Onde a arte está presente e como nos afeta? Como fazemos arte 
com as crianças? O que podemos propor para enriquecer? Experimentar além da folha A4 e da tinta guache. Os professores cursistas sentiram-se desafiados e provocados a criar com base no que iam aprendendo e experimentando nas vivencias com os formadores especialistas.

$\mathrm{Na}$ vivência de artes com a formadora especialista Luciana Ostetto, os cursistas foram levados a puxar da memória seus momentos com a arte e inúmeras histórias de traumas e boas lembranças eram trazidas para as reflexões no encontro com a articulação. Aproveitamos também para tratar do registro como instrumento de avaliação e reflexão do trabalho. Com o intuito de ampliar os repertórios e possibilitar o encontro com uma bibliografia especializada sobre o assunto, disponibilizamos - em todo o módulo - alguns textos de autoras como Patricia Corsino, Maria Isabel Leite, Zilma Ramos de Oliveira, Daniela Guimarães e a própria Luciana Ostetto, que trazem uma visão compatível com a que temos acerca do trabalho na Educação Infantil, e vídeos que tratavam dos temas. Esses materiais eram enviados por email e também compartilhados no grupo que criamos na rede social. Ao final de todos os encontros tínhamos uma proposta-desafio para os cursistas, que seria levada para suas unidades escolares e turmas, a fim de que um pouco do que era proposto aos seus corpos fosse experimentado nos corpos das crianças. Nesse momento, desafiamos o grupo a registrar visualmente a atividade que consideravam como sendo a melhor que faziam com suas turmas e, a partir desse registro, formular uma escrita reflexiva acerca da atividade realizada, da sua relação com o planejamento, dos envolvimentos que teve com as crianças, avaliando-a.

Com a formadora Moema Quintanilha, os cursistas traziam poesias e encantamentos ao criarem composições com objetos do quintal da universidade e pensavam como era simples propor isso às crianças. Colocamos então em discussão as diferentes linguagens artísticas e a forma como elas estão sendo inseridas nas escolas: o que estamos oferecendo para o olhar das crianças? Há intencionalidades nas propostas que levamos para elas? Arte para quê? Quais materiais oferecemos para as crianças? Deixamos que explorem, descubram, desconstruam? Qual é o tempo da arte? Como anda nosso tempo subjetivo? Damos para as crianças o tempo que elas necessitam? Essas questões foram lançadas para que discutíssemos esse lugar que a arte tem - ou deveria ter - nas instituições de Educação Infantil e o quão próprias são das práticas desses profissionais que atuam nesse segmento. Buscando integrar teoria e prática, propusemos que cada cursista pensasse e realizasse pelo menos uma atividade artística que nunca tivesse feito com sua turma, registrando visual e reflexivamente. É importante dizer que esses registros eram compartilhados na rede social e entregues às formadoras, tornando-se valiosa fonte para nossa pesquisa.

Da oficina com a formadora Terezinha Lozada, surgiram várias falas sobre a apreciação da arte e muitas ideias para visitar espaços e museus com as crianças. Por isso então o tema espaço 
foi abordado nesse contexto. Como organizar o ambiente? Como criar, inovar e utilizar os famosos "cantinhos" que aparecem como próprios das salas de educação infantil? Como valorizar os espaços que temos, construindo neles e com eles relações? Aqui a proposta transcendeu as paredes das salas e foi tomar corpo e se apropriar da área externa do prédio $\mathrm{CCH}$ (Centro de Ciências Humanas) - onde habitualmente realizávamos os encontros desse módulo. Assim, espalhados e mergulhados em materiais e ideias construímos coletivamente propostas de espaços que remetessem a ações e sensações. Poderíamos ter, portanto, um espaço que primasse pela arte com o intuito de causar curiosidades, outro que possibilitasse experimentações matemáticas ou ainda que trouxesse surpresas ao brincar.

A organização do curso foi apontada por uma aluna: "a maneira como são organizadas as aulas é suave e prazerosa. Não é cansativa como a maioria dos cursos de formação.” M.O. E assim fomos desenhando a articulação. Cada proposta era postada pelos professores cursistas no grupo do curso na rede social para compartilhar suas atividades com as crianças. Com os cuidados necessários de exposição ou autorização do uso de imagem. Fizemos um levantamento sobre quem tinha acesso à rede e somente uma aluna não demonstrou interesse em utilizá-la. Todos os demais eram ativos ou passaram a utilizar mais essa ferramenta. Semanalmente então esses registros eram postados. Os encontros após as oficinas serviram também para estreitar relações, os educadores foram fazendo amizades e trocando experiências de lugares que trabalhavam, alguns descobriram que conviviam perto.

Uma aluna escreveu em seu registro assim: "Esperava um curso mais escrito sobre como fazer, como não fazer, ou seja, ensinando você a fazer arte." O tema arte no título do curso havia atraído muitas pessoas, até educadores formados em arte que trabalhavam com crianças. Assim, nos encontros fomos refletindo sobre o conceito e as atividades de artes que oferecíamos as crianças: será que arte na escola só serve para produzir? É só para fazer trabalhinhos e colocar na pasta ou no mural? Nessas provocações os professores cursistas recorriam aos superiores para culpar pela orientação das atividades até chegarmos a pensar sobre quem fazia as escolhas no momento do planejamento. Somos nós, educadores, que planejamos atividades para a criança criar e experimentar a arte.

Os cursistas traziam para o encontro seus conflitos frente ao que descobriam. Dentre os relatos sobre as expectativas com o curso encontramos "estou aqui para trocar experiências de vida, não só profissional, e ampliar minha visão, romper barreiras”. Era comum discutirem sobre as dificuldades de estar ali, as obrigações com a família, a jornada de trabalho semanal exaustiva que não favoreciam o curso, mas diziam estarem gostando da experiência e que esta fazia bem à vida pessoal e profissional, pois ampliava seu entendimento para além das questões de cuidado e 
educação de seus alunos. As visitas aos museus eram impregnadas de sentido, conhecer lugares desconhecidos e fora de sua região era sempre positivo. Elas também motivaram saídas com as crianças, pois os educadores cursistas quiseram compartilhar suas vivências nesses espaços, até então pouco explorados.

E após três encontros, outro módulo foi iniciado. Inicialmente as oficinas de consciência corporal não provocaram tanto interesse nos cursistas. E já percebíamos o lugar do corpo nas propostas para as crianças. A arte e as produções artísticas pareciam mais interessantes e mais privilegiadas nas rotinas. O professor cursista demonstrava que o papel, a caneta e a produção vêm em primeiro lugar, ainda na escola de educação infantil. Assim, apresentamos os formadores especialistas para o grupo pela rede social. Cada qual com sua trajetória importante e com uma contribuição significativa para a área da consciência corporal.

A mudança das aulas do prédio da educação para o prédio de artes cênicas já provocou um movimento. Os educadores em formação estavam alegres e curiosos pelas salas de piso e acústica adequada. Os professores especialistas e seus grupos começaram as experiências que visavam o autoconhecimento e as possibilidades do próprio corpo. Alguns cursistas de maior idade adequavam-se às propostas e mostravam-se bem interessados em alongar, respirar e (re)conhecer o próprio corpo.

Para os encontros buscamos referência nos textos do Salto para o futuro, o corpo na escola e no livro Expressão corporal na pré escola, de Patricia Stokoe e Ruth Harf. Os educadores falavam que estavam leves, relaxados e pensando como o corpo aguenta a pressão do dia a dia. As discussões foram em torno do aprisionamento dos corpos e seu tolhimento nas práticas escolares. Apontamos inúmeras práticas enraizadas no cotidiano da creche e das escolas que visavam à normatização e disciplina.

Como esse contexto escolar que busca disciplinar corpos e mentes, como se fosse possível separá-los, se expressa nas relações cotidianas entre professores e alunos? Quais práticas reforçam essa busca incessante pelo controle dos corpos? Como podemos ver essa tentativa de disciplinarização na disposição dos espaços físicos das salas de aula? Essas foram algumas das questões levantadas na mediação, mas que surgiram também de provocações feitas pelos professores especialistas, ao ressaltar a importância do espaço: "Espaço para se mover, morder, balançar. Nós precisamos educar com uma flexibilidade, um olhando para cada um. O corpo dá essa possibilidade de brincar", diz a Professora formadora Érica Reis. E foi retomando essas falas e as sensações que ficaram no corpo desses educadores que refletimos acerca da forma como o corpo da criança vem sendo visto e tratado nas escolas de Educação Infantil. Cada um voltou para si e, por meio de desenho, expressou a parte do seu corpo que considerava fundamental no trabalho 
com as crianças. É incrível perceber como as concepções com as quais tivemos contato por toda uma vida nos influenciam, mesmo quando experimentamos uma proposta completamente oposta. O resultado disso foi uma chuva de mãos, cabeças, olhos e pernas, evidenciando a nossa predisposição em comandar, guiar, conduzir. Já quando focamos na criança, a mudança na forma como ela se relaciona com o mundo fica evidente. Pedimos que cada educador se remetesse à sua realidade e, também por meio de desenho, registrasse a parte do corpo mais utilizada pelas crianças no dia a dia. Não é de surpreender que quase unanimemente aparecesse o corpo inteiro. Quando abrimos para a discussão em grupo essa diferença ficou muito clara e provocou muita inquietação nos educadores cursistas. Esse foi o momento para pedirmos uma escrita reflexiva sobre a rotina de seus corpos na escola, registrando como esse corpo se comporta na rotina com as crianças, quais partes realmente são utilizadas, de que forma e para quê. A ideia era que parassem para perceber seus corpos, estudando os movimentos, as respostas que o corpo dá e as intencionalidades de suas ações, pois acreditamos que a experiência é algo que necessita da percepção, de um tempo para a apreciação e reflexão, compartilhamos da crença de Larrosa ao dizer que:

A experiência, a possibilidade de que algo nos aconteça ou nos toque, requer um gesto de interrupção, um gesto que é quase impossível nos tempos que correm: requer parar para pensar, parar para olhar, parar para escutar, pensar mais devagar, olhar mais devagar, e escutar mais devagar; parar para sentir, sentir mais devagar, demorar-se nos detalhes, suspender a opinião, suspender o juízo, suspender a vontade, suspender $\mathrm{o}$ automatismo da ação, cultivar a atenção e a delicadeza, abrir os olhos e os ouvidos, falar sobre o que nos acontece, aprender a lentidão, escutar aos outros, cultivar a arte do encontro, calar muito, ter paciência e dar-se tempo e espaço. (LARROSA, 2014, p.25)

Partindo de uma visão mais sensível, com um corpo mais permissivo ao toque do outro e mais receptivo às sensações que o invadem, buscamos novamente as conexões entre esse corpo que toca e é tocado; que pensa as atividades, mas nem sempre está incluído nelas; que está presente na teoria e ao mesmo tempo muito distante na prática com as crianças pequenas. Como isso pode acontecer? Consigo afetar o corpo do outro sem ter o meu afetado? Esse foi um dos pontos trabalhados pelo professor especialista Alexandre Beringh, que lança no grupo a seguinte informação: "precisamos sentir o nosso corpo para nos conhecer. Quando reconhecemos o nosso corpo podemos levar a criança a conhecer o dela. Autoestima e autoconhecimento em nós para proporcionar aos outros". E assim surgiu a proposta de realizar uma atividade com as crianças que tivesse o objetivo de mexer com o corpo todo, recheada de intencionalidades e amparada pela percepção, destacando os seguintes pontos: as crianças tocam seus corpos? E o dos colegas? E o do seu professor? O que as crianças mais gostam de fazer com o corpo? O que é mais fácil e mais 
difícil delas fazerem? Há limites para o corpo infantil? Aos poucos eles foram percebendo que o corpo - inclusive o deles próprios - pode mais do que se imagina, basta dar-lhe oportunidade.

Encerrando esse módulo pudemos mergulhar fundo em nossos sentidos, saboreando gostos, texturas, imagens, cheiros e sons. Toda a percepção corporal, tão bem explorada pela professora especialista Maria Enamar, ao convidá-los a observarem sua respiração, sentindo cada parte de um corpo muitas vezes aparentemente adormecido, foi potencializada num banquete em que figuravam essências, especiarias, alimentos, lixa, algodão, esponja, sagu mergulhado na água, plástico bolha e muito Bartolomeu Campos de Queirós e sua poesia sobre os sentidos. O resultado não poderia ser outro, senão entrega e prazer. Da mesma forma, a proposta a ser feita com as crianças não poderia ser outra, explorar seus sentidos.

Toda essa movimentação no curso refletiu nas escolas onde nossos professores cursistas atuavam. Eles colocaram em um dos encontros que os colegas que não estavam nas vivências do curso não entendiam as propostas levadas para as crianças. Causava estranhamento oferecer a pintura com os pés, o respirar e o observar antes de conversar. Também disseram que levavam os textos para discutirem com os colegas de trabalho nas escolas, uma vez que apontaram a ausência de uma proposta de consciência corporal nas instituições.

Os outros módulos - dança, literatura e teatro - seguiram o mesmo formato: vivenciar, dialogar, refletir, ressignificar e experimentar com as crianças. Entre eles ainda tivemos uma visita ao Museu das Telecomunicações Oi Futuro para participar de um Encontro de Multiplicadores; a exibição do filme Tarja Branca, com posterior debate com uma artista do elenco e toda a equipe de coordenação e formação do curso e a participação no Fórum Fina Flor, promovido pela UNIRIO que contou com atividades diversas envolvendo o tema cooperação.

E assim, o desafio de mediar e articular as experiências e propostas do programa do curso com as práticas do cotidiano foi vivido com dedicação, buscando ao máximo legitimar e escutar (abrir espaço para expressão) das conexões e vivências de cada cursista. Estamos todos acostumados com aulas de formação nas universidades, onde estamos dispostos de maneira a ouvir e movimentar a mão para falar e debater o assunto ensinado. Foi preciso reinventar esse lugar de dar voz a reflexão, as ideias e as trocas de saberes. Podemos conhecer inúmeras técnicas e modos de fazer arte, por exemplo, mas perceber o que será viável e interessante vai além desse conhecimento. Na hora de planejar uma atividade vamos buscar no que somos, o que fizemos ou o que a criatividade sussurra ao pé do ouvido para ser feito. Por isso, a formação que nos torna conhecidos de nós mesmos faz a diferença no meio dos despropósitos em que nos aventuramos com as crianças. Como podemos propor na escola o que acreditamos ser mais próximo, pertinente a cada criança, cada grupo? Como propor atividades mais sensíveis? Com essas questões seguimos 
buscando a relação entre o autoconhecimento, a sensibilidade e as práticas pedagógicas, sobretudo aquelas que versam diretamente sobre a formação do educador.

\title{
Atenção para escutar! O que aprendemos de verdade?
}

\author{
"Vai sem direção. Vai ser livre! A tristeza não, não resiste. Solte os seus \\ cabelos ao vento, não olhe para trás. Ouça o barulhinho que o tempo no \\ seu peito faz. Faça a sua dor dançar. Atenção para escutar. O que você \\ quer saber de verdade (...)". Marisa Monte (2011).
}

Ficou claro ao longo do curso que ainda há um forte sentimento de que existem técnicas, métodos e regras fechadas quanto ao educar na Educação Infantil. E que por isso, uma proposta que se mostre inovadora, estando pautada na vivência do professor, ainda causa estranhamento e até traz o abandono do curso. Isso também deixa claro o quanto ainda dissociamos corpo e mente, como se fosse possível educar ressaltando um em detrimento do outro.

Compreendemos a importância da articulação entre as atividades propostas, a interação dos professores, o aguçar das sensibilidades e a presença da afetividade, que permeia todo o percurso. Por isso o curso é construído sob a percepção de que não há como apreender algum conhecimento, sem senti-lo. A aprendizagem começa no corpo, passa por ele, se processa por meio dele, e é aí que a necessidade do vivencial está pautada e garantida. Acreditamos que isso se faz mais do que necessário, mas urgente na realidade dos espaços escolares, principalmente de Educação Infantil, onde nos deparamos com corpos precarizados, instituídos e diariamente violentados, tanto dos educadores quanto dos educandos, como nos mostram pesquisas como de Arroyo (2012).

As crianças, desde as menores idades, são moldadas, silenciadas, tolhidas em sua espontaneidade e expressão. Compactuamos com uma educação pautada em trabalhinhos estereotipados, desenhos reproduzidos em série e uma busca frenética por transmitir conteúdos, em detrimento de proporcionar vivencias significativas, que ampliem o repertório cultural das crianças, deem-lhes autonomia, estimule a criatividade e a construção do conhecimento. Pensando nisso, apresentamos uma proposta de curso de extensão que proporcionou que esses conflitos fossem vivenciados e que outros modos de encontrarmos o corpo, a teoria e a prática no campo da educação fossem inventados. Nesse modelo de formação, o professor não foi mero expectador, que colhia receitas prontas, mas um vivente, "experimentante" de práticas que primavam pelo sensível, pelo afetamento do encontro com seu 'eu' e dele com o(s) outro(s), pois concordamos com Loponte (2011, p. 42-43) quando cita Fischer (2009, p. 94): 
Além de um lugar de lamentação e impossibilidades diárias, a docência pode ser lugar mesmo de onde talvez seja possível não exatamente pensar nossos limites e as forças que nos constrangem, mas as condições e possibilidades infindas, imprevisíveis e indefinidas de nos transformarmos e de sermos diferentes do que somos.

O curso nos traz então um entrelaçamento entre escola, universidade, professores, alunos, individual, privado e coletivo, costurando por meio da afetividade e das vivências uma rede de (des)encontros, conquistas, reflexões, onde o centro é a busca por uma educação mais viva, afetiva, próxima da criança e que está intimamente ligada aos processos formadores dos profissionais que com elas atuam. Para que esse professor tenha essa formação estética deve abrir-se à experiência do sensível. Não só com relação às crianças, mas a si mesmo. Uma formação estética tem então, que começar pelo educador, de forma que seus sentidos sejam alargados da mesma forma que o mar quando olhamos para o horizonte. Seu corpo deve estar aberto como as asas de um pássaro ao sobrevoar as rochas. E a mente, aberta como um guarda-chuva em dia de temporal, mesmo que nos molhemos um pouco, afinal, como é bom tomar um banho de chuva! Vivências! Essa é a palavra de ordem. O estético reside nas vivências e no que fazemos com elas.

Ficou claro o quanto nós professores ainda temos dificuldades para colocar o corpo em evidência. Percebemos da mesma forma que os sujeitos têm facilidade para falar dos outros e do que fazem, mas grande dificuldade para se colocarem nessas falas, expressando seus desejos, vontades e pensamentos, como sujeitos autores de seus processos. Nesse ponto o curso mostrouse como transformador, pois ao vivenciar e exercitar a autoria por meio da oralidade, das narrativas, da escrita, da documentação, os professores tornam-se mais sensíveis em suas práticas e também nas ações. Isso fica muito claro ao compararmos os registros do início do curso com os do final, fazendo com que percebamos mudanças na própria escrita como também na forma como pensam as questões que foram colocadas. Essa mudança também foi vista nas práticas com as crianças. Conforme o curso ia acontecendo, as propostas em sala iam se tornando mais sensíveis. E quem mais ganhou com isso, com certeza foram as crianças. Esse é o lugar do corpo na escola, no qual nos esforçamos por fazê-lo existir: um lugar subjetivo, repleto de imaginações e ações. Não mais aquele corpo que mexe, pula, faz atividades físicas, mas corpo vivo, disponível para construir um cotidiano nas creches e pré-escolas repleto de possibilidades para expressões.

Sentimos aí que cumprimos com alguns desafios, pois ficou evidente que para que o professor possa efetivamente incorporar em sua prática ações que envolvam o estímulo a criatividade, o fomento a imaginação das crianças, oferecendo experiências que envolvam a corporeidade, a produção artística e a formação cultural e estética, é mister que ele próprio 
experimente em si mesmo essas possibilidades, convicção orientada pelos estudos do campo da formação docente, dentre outros (DUARTE JR. 2000; LOPONTE, 2011; NUNES, CORSINO e KRAMER, 2011).

As vivências entre os cursistas e as professoras formadoras nos trouxeram uma maior possibilidade de perceber as conexões feitas entre o que foi vivido por eles e as referências que já traziam consigo. A cada sábado, com as propostas de experimentação, os diálogos e registros, ia ficando mais claro os sentidos que estavam sendo atribuídos ao curso e de que forma esses afetamentos estavam repercutindo nas escolas em que trabalhavam. Uma coisa é certa, os cursistas passaram a experimentar mais em suas salas, ousaram, ampliaram não só repertórios, mas espaços e momentos de escuta. As experiências traziam novos sentidos, pois os docentes estavam diferentes. Conseguiam enxergar as possibilidades mesmo nos lugares mais improváveis, estavam dispostos a pensar com o corpo todo, abertos e suscetíveis. Claro que esse processo não aconteceu de um dia para o outro. Ao contrário, foi acontecendo ao longo do curso, mas se deu de forma mais efetiva após o seu término, quando as vivencias e reflexões puderam ir sendo postas a prova.

(...) E a experiência é o que nos passa e o modo como nos colocamos em jogo, nós mesmos, no que se passa conosco. A experiência é um passo, uma passagem. Contém o 'ex' do exterior, do exílio, do estranho, do êxtase. Contém também o 'per' de percurso, do passar através, da viagem, de uma viagem na qual o sujeito da experiência se prova e se ensaia a si mesmo. E não sem o risco: no experiri está o periri, o periculum, o perigo. Por isso a trama do relato de formação é uma aventura que não está normatizada por nenhum objetivo predeterminado, por nenhuma meta. $\mathrm{E}$ o grande inventor-experimentador de si mesmo é o sujeito sem identidade real nem ideal, o sujeito capaz de assumir a irrealidade de sua própria representação e de submetê-la a um movimento incessante ao mesmo tempo destrutivo e construtivo. (LARROSA, 2014, p. 57)

\section{REFERÊNCIAS BIBLIOGRÁFICAS}

ARROYO, Miguel (Orgs.). Corpo-infância: exercícios tensos de ser criança; por outras pedagogias dos corpos. Petrópolis, RJ: Vozes, 2012.

DUARTE JUNIOR, João Francisco. O sentido dos sentidos: a educação (do) sensível. 234f. Tese (Doutorado em Educação) - Universidade Estadual de Campinas, Campinas, 2000. . A montanha e o vídeo-game: escritos sobre a educação. São Paulo:

Papirus, 2010. . Entrevista. Contrapontos, São Paulo, v. 12, n. 3, set-dez 2012. Disponível em: http://siaiap32.univali.br/seer/index.php/rc/article/viewFile/4039/2387 LARROSA, Jorge. Tremores: escritos sobre experiência. Belo Horizonte: Autêntica, 2014. 
LOPONTE, Luciana Gruppelli. Arte e inquietudes estéticas para a educação. In PASSOS, Mailsa Carla Pinto. Educação como experiência estética. Rio de Janeiro: NAU, 2011 (30-51). NUNES, Maria Fernanda; CORSINO, Patrícia; e KRAMER, Sonia. (orgs). Educação Infantil e Formação de profissionais do Estado do Rio de Janeiro (1999-2009) - Relatório de Pesquisa. Rio de Janeiro: Traço e Cultura, 2011.

PENA, Alexandra; BOGÉA, Isabel C.; BORGES, Leonor Pio. Aconchegando o corpo na escola: as perspectivas - pensando o lugar do corpo na escola. In: O Corpo na escola. Salto para o Futuro. MEC, 2008.

RESENDE, Catarina. O que pode um corpo? O método Angel Vianna de conscientização do movimento como um instrumento terapêutico. Phisys: Revista de Saúde Coletiva, Rio de Janeiro, v.18, n. 3, set. 2008 .

SCHLINDWEIN, Luciane Maria. Arte e desenvolvimento estético na escola in PINO, Angel; SCHLINDWEIN, Luciane Maria e NEITZEL, Adair de Aguiar. Cultura, escola e educação criadora, formação estética do ser humano. Curitiba: Ed CRV, 2010.

SOARES, Maria Luiza Passos. Educação Estética - investigando possibilidades a partir de um grupo de professoras. 99f. Dissertação (Mestrado em Educação) - Universidade do Vale do Itajaí, Itajaí, 2008.

TREZZI, Clóvis. Schiller e Freire: um olhar sobre a educação estética. Revista Eletrônica de Ciências da Educação. Campo Largo, v.10, n. 1, p.68-77, jul. 2011.

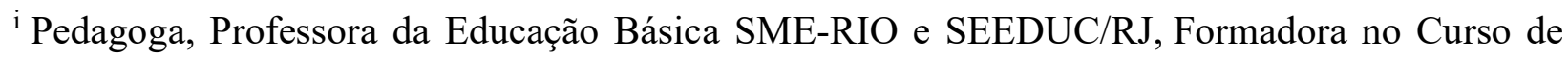
Extensão Corpo, Arte e Natureza - UNIRIO

ii Professora Adjunta da Universidade Federal do Estado do Rio de Janeiro. Coordenadora adjunta dos cursoa de pós graduação em Docência da educação Infantil e de Extensão em Educação Infantil do convênio Unirio- MEC

${ }^{\text {iii }}$ Mestre em Psicologia Social UERJ, diretora da casa monte alegre educação infantil, dirigindo práticas escolares e formando educadores nos cursos de especialização em docência da eduação infantl UNIRIO/MEC e no curso de extensão corpo, arte e natureza - UNIRIO/MEC

iv Graduanda em Pedagogia pela UERJ, Professora e Diretora Adjunta do Município do Rio de Janeiro, Formadora no Curso de Extensão Corpo, Arte e Natureza - UNIRIO/MEC.
} 